\title{
Synthesis and chemical properties of polyacetylenic derivatives of benzo- and dibenzo- crown ethers
}

\author{
Svetlana V. Klyatskaya, Eugene V. Tretyakov, and Sergey F. Vasilevsky* \\ Institute of Chemical Kinetics and Combustion, Siberian Branch of the Russian Academy of \\ Sciences, 630090 Novosibirsk, Russian Federation \\ E-mail:vasilev@ns.kinetics.nsc.ru
}

Dedicated to Professor Boris A. Trofimov, for his $65^{\text {th }}$ birthday

(received 16 Apr 03; accepted 02 June 03; published on the web 06 June 03)

\begin{abstract}
4',5'-Diethynylbenzo-15-crown-5- (6), 4',5'(5') -diethynyldibenzo-18-crown-6 (10, 11) and 4',5',4', 5' '-tetraethynyl-dibenzo-18-crown-6 (12) ethers were synthesized by cross-coupling of the corresponding di- and tetra- iodides (1-4) with trimethylsilylacetylene (5a) or 2-methylbut-3yn-2-ol (5c) followed by treatment of the resulting products with alkali. The Mannich reaction with the di- and tetraethynyl derivatives was also carried out.
\end{abstract}

Keywords: Benzocrown ethers, alkynes, cross-coupling reaction, polyethynylbenzocrown ethers, aminoalkylation, the retro-Favorsky reaction, the Mannich reaction, homogeneous catalysis

\section{Introduction}

The crown ethers are very attractive compounds for analytical and coordination chemistry as well as for pharmaceutical applications because of their ability to bind cations selectively. ${ }^{1}$ However, the chemistry of acetylenic derivatives of the crown ethers remains poorly studied owing to the limited synthetic approaches to these compounds. Only a few publications are devoted to the synthesis of acetylenylbenzocrown ethers by cross-coupling of iodoarenes with terminal acetylenes, ${ }^{2,3}$ whereas the preparation of polyethynyl-benzo-crown ethers is not described at all.

Moreover, we have found some important details, both when we tried to obtain even simple monoethynylbenzocrown ethers and when we carried out the Mannich reaction ${ }^{4}$ with them. For the above reasons, and the fact that the introduction of several acetylenic groups- especially terminal ones - into the crown ether molecules increases their synthetic and application potential through increasing their reactivity, we undertook investigations to develop methods of synthesis 
of poly(ethynyl)benzocrown ethers and to study their behavior in the cross-coupling and Mannich reactions.

\section{Results and Discussion}

The cross-coupling of aryl halides with terminal acetylenes (the Sonogashira reaction) has become a general method for the preparation of arylalkynes, ${ }^{3,5}$ and we therefore used this approach to obtain the target polyacetylenic compounds.

Since 1975, when Sonogashira et al. ${ }^{5}$ discovered the catalytic system $\left(\mathrm{PdCl}_{2}\left(\mathrm{PPh}_{3}\right)_{2}\right.$-CuI$\mathrm{Et}_{2} \mathrm{NH}$ ) for the cross-coupling of 1-alkynes with $s p^{2}$-halides, this method is considered the best one for the preparation of various aryl- and hetarylacetylene derivatives. However, the $\mathrm{Pd} / \mathrm{Cu}-$ catalyzed cross-coupling of 1-alkynes with iodoarenes having electron-donor substituents $\left(\mathrm{NR}_{2}\right.$, OR) is accompanied by homo-coupling of the alkynes and the reductive de-iodination of iodoarenes. Sometimes such side-reactions become the only ones. ${ }^{6}$ The replacement of iodine atoms by acetylenic groups in the weakly reactive polyhalobenzocrown ethers (owing to the deactivating influence of several alkoxy groups possessing $+\mathrm{M}$ effects) has not been attempted.

We have investigated the possibility of using the cross-coupling of poly-iodocrown ethers to introduce several acetylenic groups into a crown ether molecule. The starting diiodobenzocrown ethers 1-3 were synthesized by direct oxidative iodination of the corresponding ethers in an $\mathrm{I}_{2}-$ $\mathrm{HIO}_{3}-\mathrm{H}_{2} \mathrm{SO}_{4}$ system ${ }^{7}$ at $50-55{ }^{\circ} \mathrm{C}$ (yield 50-80\%) (Scheme 1). Under the above conditions, for dibenzo-18-crown-6 (2 mol of iodination mixture / mol of starting compound) a mixture of cis(2) and trans- (3) isomers was obtained in a total yield of 83\%. Tetraiododibenzocrown ether 4 $(60 \%)$ was obtained from dibenzo-18-crown-6 and $\mathrm{I}_{2}, \mathrm{NaIO}_{4}$, and $\mathrm{H}_{2} \mathrm{SO}_{4}$ in dioxane under reflux.
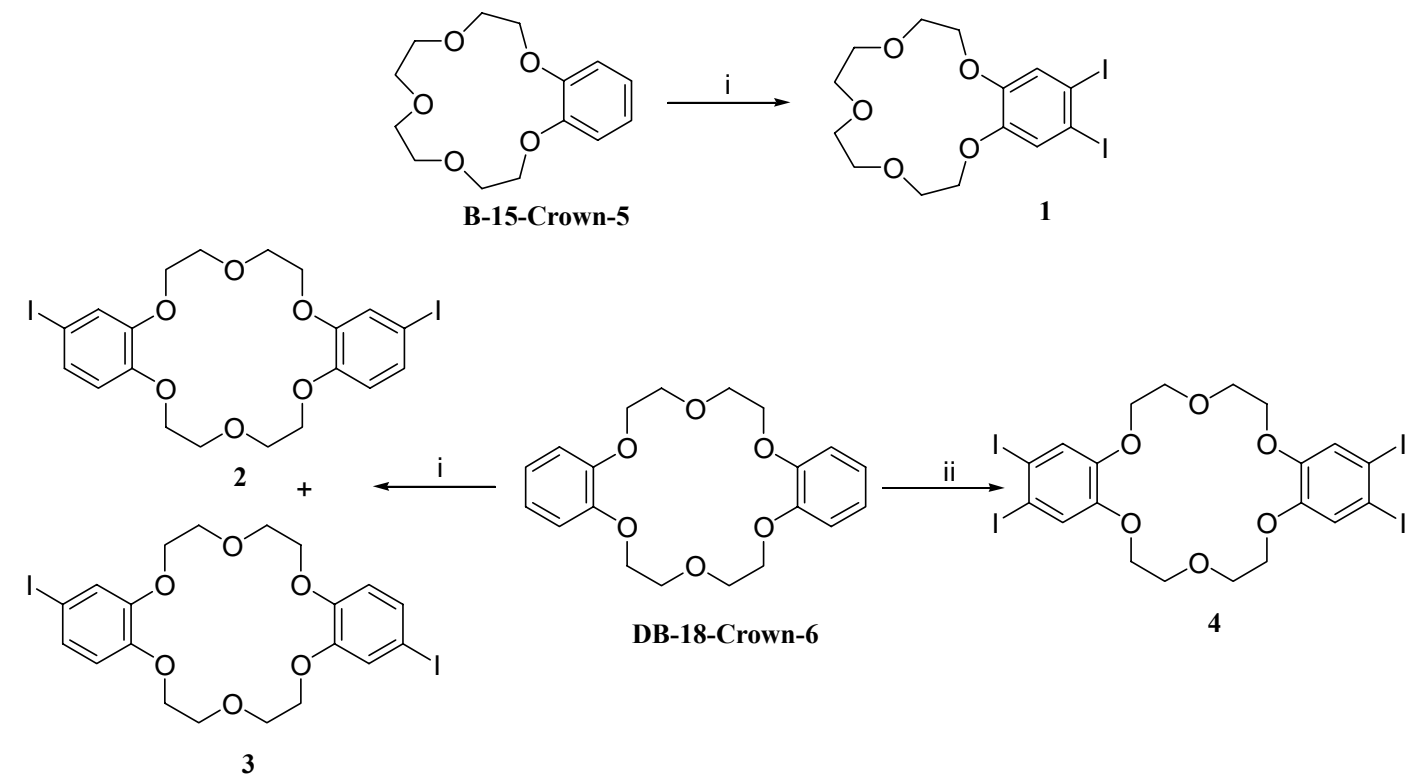
Scheme 1. i. $\mathrm{I}_{2}-\mathrm{HIO}_{3}-\mathrm{H}_{2} \mathrm{SO}_{4}$, acetic acid; ii. $\mathrm{I}_{2}-\mathrm{HIO}_{3}-\mathrm{H}_{2} \mathrm{SO}_{4}$, dioxane.

The synthesis of individual cis- (2) and trans- (3) isomers was realized from the corresponding dinitrodibenzo-18-crown ethers (2a, 3a) (Scheme 2). Nitration of dibenzo-18crown ether by nitric acid mixed with acetic acid in chloroform resulted in a mixture of cis- and trans- dinitrodibenzo-18-crown ethers, which were separated by recrystallization from DMF. ${ }^{8}$ Reduction of the nitro derivatives by hydrazine hydrate in the presence of $4 \% \mathrm{Pd} / \mathrm{C}$ in boiling ethanol ${ }^{9,10}$ led to the cis-amino- (2b, 63\%), and trans-amino- crown ether (3b, 87\%). Denitration of the isomers (2b) and (3b) was carried out in diluted $\mathrm{H}_{2} \mathrm{SO}_{4}$ followed by $\mathrm{KI}$ addition in the presence of freshly prepared $\mathrm{Cu}(0)$, as described for $p$-iodo- phenols. ${ }^{11}$ The cis-iodocrown ether (2) and trans- isomer (3) were formed in $32 \%$ and $42 \%$ yields, respectively.

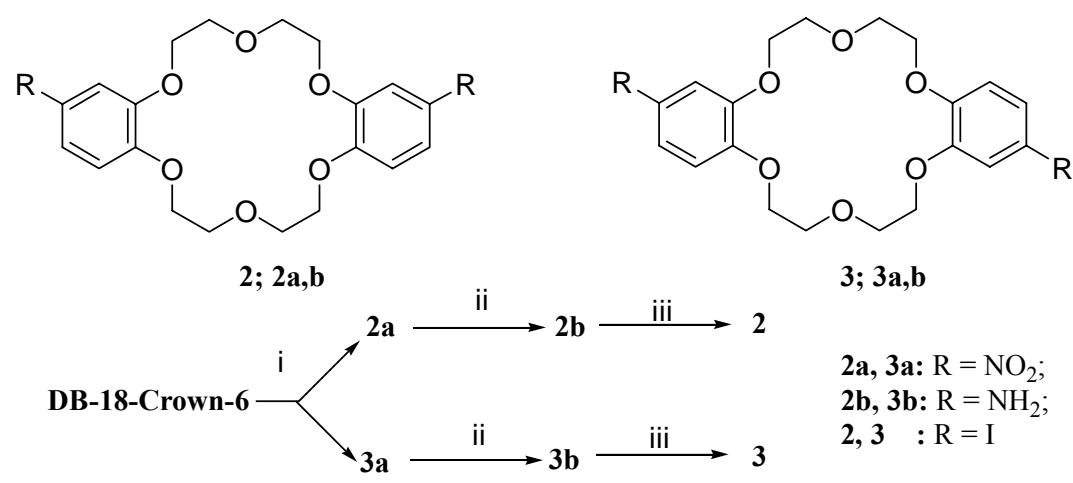

Scheme 2. i. $\mathrm{HNO}_{3}, \mathrm{CH}_{3} \mathrm{COOH}$, recrystallization from DMF. ii. $\mathrm{NH}_{2} \mathrm{NH}_{2}, \mathrm{Pd} / \mathrm{C}, \mathrm{C}_{2} \mathrm{H}_{5} \mathrm{OH}$, iii. $\mathrm{NaNO}_{2}, 5 \% \mathrm{H}_{2} \mathrm{SO}_{4}, \mathrm{KI}, \mathrm{Cu}^{0}, 0^{\circ} \mathrm{C}$.

We used trimethylsilylacetylene (5a), $p$-ethynylbenzaldehyde (5b) and 2-methylbut-3-yn-2ol (5c) as acetylenic components in the cross-coupling, ${ }^{5,12}$ of polyiodocrown ethers (1-4). A special interest in acetylenylbenzocrown ethers bearing formyl groups was caused by the possibility of their forming stable nitronyl-nitroxide radicals, since they are precursors of 2imidazoline. We have previously shown that acetylenic derivatives of heterarylnitronylnitroxides possess very interesting optical and magnetic properties. ${ }^{13}$ 2-Methylbut-3-yn-2-ol (5c) and trimethylsilylacetylene (5a) allowed the synthesis of terminal acetylenes, which are very promising key compounds, owing to their unusually high $\mathrm{CH}$ - acidity that could possibly be used both for functionalizing and building $\mathrm{C}-\mathrm{C}$ bonds.

Usually, condensation of aryl iodides with 1-alkynes has been carried out in the presence of $\mathrm{PdCl}_{2}\left(\mathrm{PPh}_{3}\right)_{2}, \mathrm{CuI}$, and $\mathrm{Et}_{2} \mathrm{NH}$ at $70-75{ }^{\circ} \mathrm{C}$ under argon. These reaction conditions proved to be inefficient in cross-coupling of iodides with $p$-ethynylbenzaldehyde (5b). In our reaction, a finely dispersed black precipitate, apparently of metallic palladium, was obtained, formed as a result of complex decomposition. Previously, ${ }^{14}$ the attempt to conduct the cross-coupling of isomeric 
bromobenzaldehydes with trimethylsilylacetylene in the presence of catalytic amounts of $\mathrm{Pd}(\mathrm{OAc})_{2}$ and $\mathrm{PPh}_{3}$ was reported: however, iodide $\mathbf{1}$ did not react with alkyne $\mathbf{5 b}$ under these conditions. It is known ${ }^{3}$ that activation of the alkynyl component with the addition of $\mathrm{CuI}$ (for aryl halides with terminal acetylenes) leads to a considerable increase in cross-coupling. We have found that the reaction of $\mathbf{1}$ with $\mathbf{5 b}$ in the system involving $\mathrm{Pd}(\mathrm{OAc})_{2}, \mathrm{PPh}_{3}$, and $\mathrm{NEt}_{3}$ in the presence of $\mathrm{CuI}$ afforded the ether $\mathbf{6 b}$ in $75 \%$ yield. The diethynyl derivative $\mathbf{6}$ was prepared from compound $\mathbf{6} \mathbf{a}$ by removing the trimethylsilyl group.

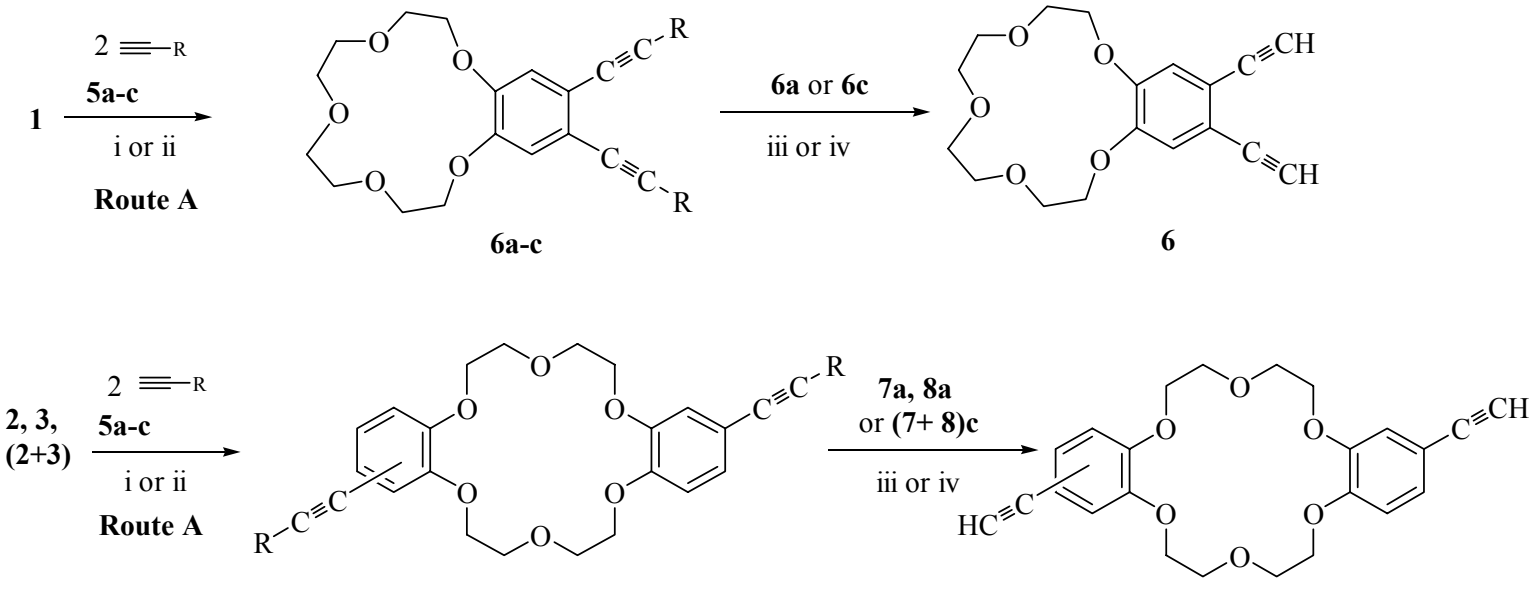

$2,7,10-$ cis

$7 \mathbf{a} ; 8 \mathbf{8} ;(7+8) \mathbf{a}-\mathbf{c}$

$10 ; 11 ;(10+11)$

$3,8,11$ - trans

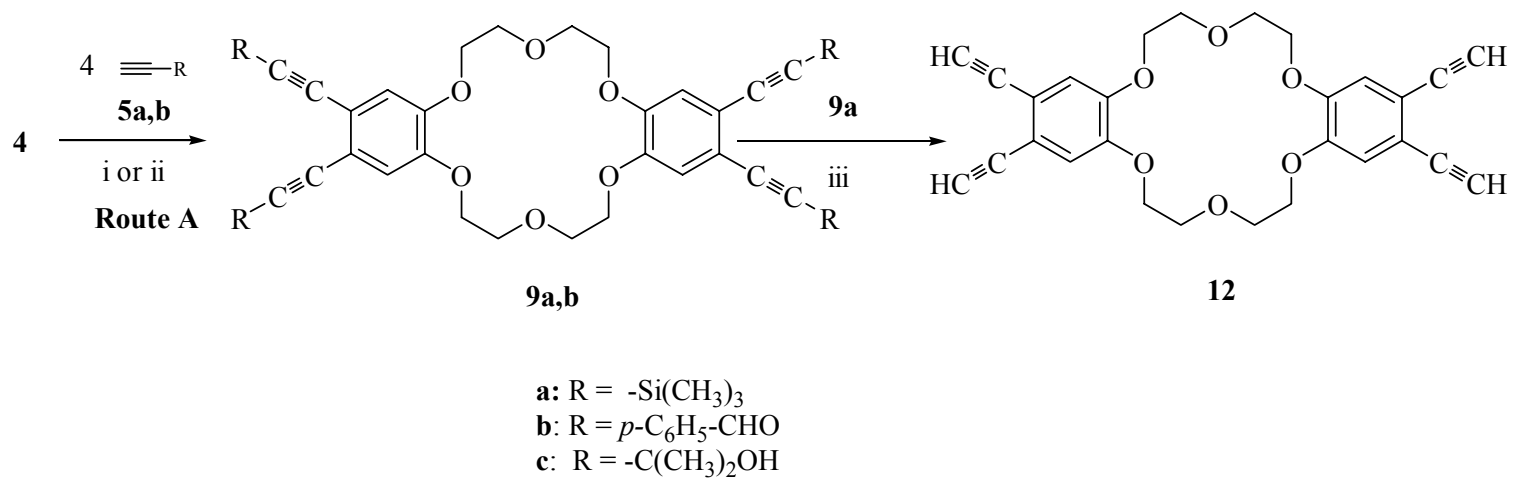

Scheme 3. i. $\mathrm{PdCl}_{2}\left(\mathrm{PPh}_{3}\right)_{2}, \mathrm{CuI}, \mathrm{NEt}_{3}$. ii. $\mathrm{Pd}(\mathrm{OAc})_{2}, \mathrm{CuI}, \mathrm{NEt}_{3}, 65-70{ }^{\circ} \mathrm{C}$. iii. $\mathrm{KOH}\left(\mathrm{K}_{2} \mathrm{CO}_{3}\right)$, methanol, $20^{\circ} \mathrm{C}$. iv. $\mathrm{KOH}$, benzene, $80^{\circ} \mathrm{C}$, or $\mathrm{KOH}$, toluene, $110^{\circ} \mathrm{C}$.

For the synthesis of poly(formylacetylenyl) crown ethers $\mathbf{6 b},(\mathbf{7}+\mathbf{8}) \mathbf{b}, \mathbf{9 b}$ we proposed a scheme involving cross-coupling of the corresponding diiodo derivatives $(\mathbf{1}, \mathbf{2 + 3}, \mathbf{4})$ with $p$ ethynyl-benzaldehyde (5b) (route A) or cross-coupling of ethynylbenzocrown ethers $(\mathbf{6}, \mathbf{1 0}+\mathbf{1 1})$ with $p$-bromobenzaldehyde 13 (route B) in the presence of $\mathrm{Pd}(\mathrm{OAc})_{2}, \mathrm{PPh}_{3}, \mathrm{CuI}$ and $\mathrm{NEt}_{3}$ in 
$\mathrm{C}_{6} \mathrm{H}_{6}$ at $40-80{ }^{\circ} \mathrm{C}$. The yields of the target compounds $(7+8) \mathbf{b}, \mathbf{6 b}$, were $50-70 \%$. One should note that the reaction duration and the yields of the products were almost identical in both routes.

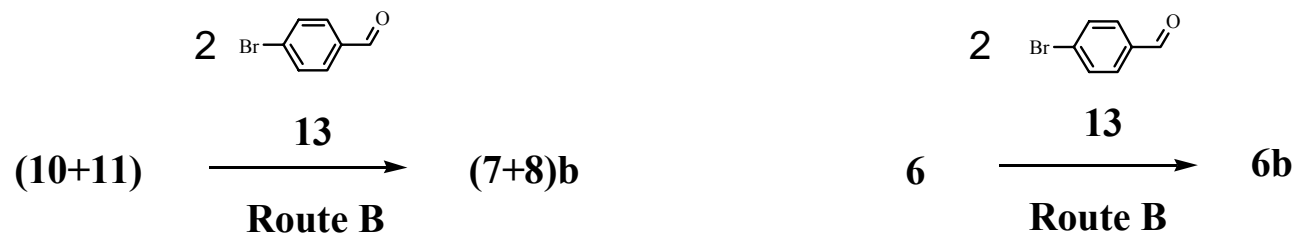

Scheme 4. i.Pd(OAc) $)_{2}, \mathrm{CuI}, \mathrm{NEt}_{3}, 65-70^{\circ} \mathrm{C}$.

The interaction of dihalobenzocrown ethers $(\mathbf{1}, \mathbf{2 + 3})$ with 2-methylbut-3-yne-2-ol $(\mathbf{5 c})$ in the presence of $\mathrm{PdCl}_{2}\left(\mathrm{PPh}_{3}\right)_{2}$ (or $\left.\mathrm{Pd}(\mathrm{OAc})_{2}+\mathrm{PPh}_{3}\right), \mathrm{CuI}$ and $\mathrm{NEt}_{3}$ led to acetylenic alcohols $(\mathbf{6 c})$ and $(7+8) \mathbf{c}$ in $60-90 \%$ yields. Since cross-coupling of the tetra-iodide 4 with butynol (5c) under these conditions was accompanied by their resinification we used trimethylsilylacetylene (5a) as acetylenic component for introduction of four ethynyl groups into benzo-crown ring. The yield of tetrakis-acetylenic derivative 9 a was $30 \%$.

The replacement of the iodine atom in $(\mathbf{1}, \mathbf{2 + 3})$ by the acetylenic moiety of the tertiary acetylenic alcohol 5c proceeded smoothly at $75-80{ }^{\circ} \mathrm{C}$ in the catalytic system $\mathrm{PdCl}_{2}\left(\mathrm{PPh}_{3}\right)_{2}$-CuI$\mathrm{Et}_{3} \mathrm{~N}$; the yield of $(\mathbf{6 c})$ and $(7+8) \mathrm{c}$ was $60-90 \%$. A mixture of diiodocrown ether, terminal acetylene, $\mathrm{PdCl}_{2}\left(\mathrm{PPh}_{3}\right)_{2}, \mathrm{CuI}$, in triethylamine was heated for $2-5 \mathrm{~h}$ at $75-80{ }^{\circ} \mathrm{C}$ under argon.

A usual way for ethynyl-arene preparations involved the cleavage of the tertiary acetylenic alcohols or the trimethylsilylacetylene derivatives by treatment with a catalytic amount of alkali. But earlier ${ }^{4}$ we discovered a specific cleavage "crown-effect" for mono-acetylenic alcohols of benzo-15-crown-5 ether and benzo-18-crown-6 ether that required an extra equimolar amount of $\mathrm{KOH}$, over that used with the corresponding benzo-12-crown-4-ether derivative. Our investigation confirmed the reverse-Favorsky reaction for diacetylenic alcohols $(\mathbf{6 c})$ and $(7+8) \mathbf{c}$ that could be realized only in the presence of the extra equimolar amount of $\mathrm{KOH}$. Ethynyl crown ethers $(\mathbf{6}, \mathbf{1 0}+\mathbf{1 1})$ were obtained by Retro-Favorsky reaction. A mixture of tertiary acetylenic alcohols $(\mathbf{6 c})$ and $(\mathbf{7 + 8}) \mathbf{c}$ and powdered $\mathrm{KOH}$ was heated at reflux in dry toluene during $2-4 \mathrm{~h}$, the yields of ethynyl crown ethers $(\mathbf{6}, \mathbf{1 0}+\mathbf{1 1})$ were $25-30 \%$. Ethynylbenzocrown ethers could also be obtained in another way. For example, the reaction of iodobenzocrown ethers 1-4 with trimethylsilylacetylene 5a led to disubstituted acetylenes (6-9)a in 70-90\% yields. Treatment of (6-9)a with $\mathrm{KOH}$ or $\mathrm{K}_{2} \mathrm{CO}_{3}$ in methanol at room temperature resulted in 6 , 10-12 in 50-60\% yields.

The ethynylbenzocrown ethers did not undergo a Mannich reaction that was carried in the presence $^{15}$ of copper(I) salts. It is known ${ }^{1}$ that the crown ethers are able to form complexes not only with appropriately sized cations ( $\mathrm{K}^{+}$-crown-6), but also with the large ones in a "sandwich" type complex. We found ${ }^{4}$ unusual behavior of ethynylcrown ethers in these conditions. ${ }^{15}$ 
Taking into account the high biological activity of compounds having a propargylamino fragment $\left(\mathrm{N}-\mathrm{CH}_{2}-\mathrm{C} \equiv \mathrm{C}\right)$, we carried out the aminoalkylation reaction on the obtained alkynes $(\mathbf{6}$, 10+11).

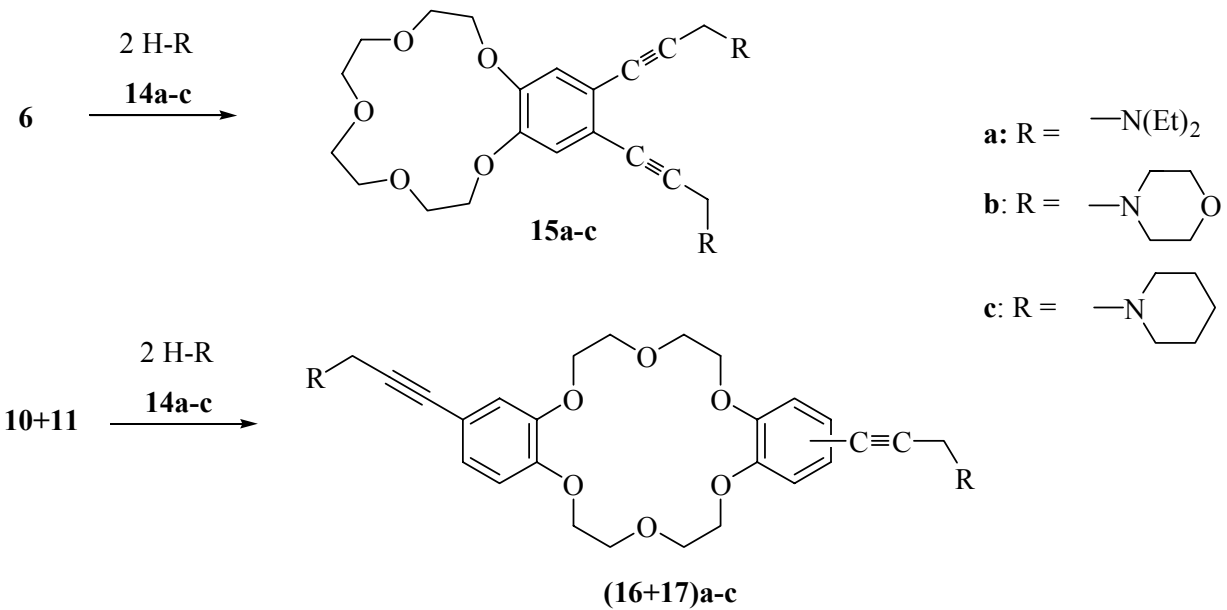

Scheme 5. i. $\left(\mathrm{CH}_{2} \mathrm{O}\right)_{\mathrm{x}}$, amine (14a-c), $\mathrm{Cu}(\mathrm{OAc})_{2}, 30 \% \mathrm{H}_{2} \mathrm{SO}_{4}$, dioxane, $80{ }^{\circ} \mathrm{C}$.

The typical procedure for aminoalkylation of ethynylarenes involved interaction of secondary amines with paraformaldehyde under reflux in dioxane in the presence of $\mathrm{CuCl}$. To avoid the problems we found earlier for mono-ethynylcrown ethers ${ }^{4}$ for the Mannich condensation, the aminoalkylation was carried out in the presence of $\mathrm{Cu}(\mathrm{OAc})_{2}$ and $30 \%$ sulfuric acid.

Aminopropargylcrown ethers 15a-c, $(\mathbf{1 6}+\mathbf{1 7}) \mathbf{a}-\mathbf{c}$ were obtained by the condensation of alkynes $(6,10+11)$ with paraformaldehyde and secondary amines $14 a-c$ in the presence of catalytic amounts of $\mathrm{Cu}(\mathrm{OAc})_{2}$ under reflux in dioxane $(1.5-2 \mathrm{~h})$. Yields of the Mannich bases were $70-80 \%$ and depended on the reaction conditions and the nature of the starting amines.

The IR and NMR spectra of $\mathbf{2}$ and $3 ; 7 \mathbf{a}$ and $\mathbf{8 a} ; \mathbf{1 0}$ and $\mathbf{1 1}$ had barely perceptible differences. From reference data for nitro- ${ }^{8,10,16,17}$ and amino derivatives ${ }^{10,18}$ [2a, 203-205 ${ }^{\circ} \mathrm{C}\left(200-201^{\circ} \mathrm{C}\right),{ }^{10}$ 3a, $\left.243-247^{\circ} \mathrm{C}\left(247-252^{\circ} \mathrm{C}\right),{ }^{16} \mathbf{2 b}, 179-181^{\circ} \mathrm{C} \quad\left(180-182^{\circ} \mathrm{C}\right), \mathbf{3 b}, 194-197^{\circ} \mathrm{C}\left(199-203^{\circ} \mathrm{C}\right)^{18}\right]$ we supposed the compounds with lower melting points to be the trans- isomers (iodo- and ethynyl derivatives), and vice versa for the trimethylsilyl derivatives (Table).

\section{Conclusions}

In summary, we have established that $\mathrm{Pd}-\mathrm{Cu}$ - catalyzed cross-coupling of polyiodobenzo- and dibenzo- crown ethers with terminal acetylenes is a convenient method for the introduction of several acetylenic groups into one molecule of the crown ether. The ease of both the introduction and elimination of the protective silyl and alcohol groups makes this procedure attractive for 
preparing polyfunctional synthons, such as polyethynylbenzocrown ethers. A series of the Mannich bases has been synthesized by aminoalkylation of ethynyl derivatives.

\section{Experimental Section}

General Procedures. Melting points were determined with a hot-stage microscope. Column chromatography was performed on silica gel (Merck 60, 70-230 mesh). The $R_{\mathrm{f}}$ values were measured on aluminum-backed TLC plates of silica gel Silufol UV-254, with the indicated eluent. NMR spectra were recorded on a "Bruker Avance 300 " spectrometer at $25{ }^{\circ} \mathrm{C}$. ${ }^{1} \mathrm{H}$ NMR chemical shifts ( $\delta$ in ppm) were given from internal $\mathrm{CHCl}_{3}(7.26)$ or $\mathrm{DMSO}-d_{6}(2.5)$ standards. Coupling constants $\left(J\right.$ in $\mathrm{Hz}$ ) were accurate to $\pm 0.2 \mathrm{~Hz}$ for ${ }^{1} \mathrm{H}$. Mass spectra (HRMS) at $70 \mathrm{eV}$ using the electron impact mode were recorded on a Finnigan SSQ-710. The IR spectra were recorded in $\mathrm{KBr}$ pellets on a "Bruker IFS 66" instrument.

$p$-Bromobenzaldehyde, ${ }^{19}$ and $p$-ethynylbenzaldehyde ${ }^{20}$ were synthesized according to known procedures. $\mathrm{Pd}\left(\mathrm{PPh}_{3}\right)_{2} \mathrm{Cl}_{2}, \mathrm{Pd}(\mathrm{OAc})_{2}, \mathrm{NaNO}_{2}, \mathrm{NaIO}_{4}, \mathrm{KI}, \mathrm{I}_{2}, \mathrm{CuI}, \mathrm{PPh}_{3}$, 2-methylbut-3-yn-2-ol, and ethynyltrimethylsilane ("Aldrich") were commercially available reactants. All the organic solvents were of analytical quality. See Table on page 231.

3,4-Diiodobenzo-15-crown-5 (1). A mixture of iodine $(2.0 \mathrm{~g}, 8.2 \mathrm{mmol})$ and $\mathrm{HIO}_{3}(1.5 \mathrm{~g}, 8.5$ mmol) was slowly added by portions to a stirred solution of benzo-15-crown-5 (2.7 g, 10.1 $\mathrm{mmol})$ in a mixture of $80 \%$ acetic acid $(40 \mathrm{~mL})$ and $30 \%$ sulfuric acid $(5 \mathrm{~mL})$. The reaction mixture was stirred to its discoloration during $2 \mathrm{~h}$ at $50-55{ }^{\circ} \mathrm{C}$, and then cold water $(300 \mathrm{~mL})$ was added. The solution was washed with $30 \% \quad \mathrm{Na}_{2} \mathrm{SO}_{3}$ aq. and extracted with $\mathrm{CHCl}_{3}$ $(3 \times 100 \mathrm{~mL})$, the organic layer was dried over $\mathrm{Na}_{2} \mathrm{SO}_{4}$, filtered through a $\mathrm{SiO}_{2}$ bed (height/diameter of the column: $2.5 \times 2 \mathrm{~cm}$ ). The solvent was removed in vacuo and the residue recrystallized from a mixture of benzene-hexane. The yield of 1 was $3.9 \mathrm{~g}(75 \%), \mathrm{mp} 97-99{ }^{\circ} \mathrm{C}$. 1H NMR data: $\delta\left(\mathrm{CDCl}_{3}\right) 3.67-3.75\left(8 \mathrm{H}, \mathrm{m}, 2 \mathrm{CH}_{2} \mathrm{OCH}_{2}\right), 3.76-3.85\left(4 \mathrm{H}, \mathrm{m}, 2 \mathrm{ArOCH}_{2} \mathrm{CH}_{2}\right)$, 4.10-4.20 (4H, m, $\left.2 \mathrm{ArOCH}_{2} \mathrm{CH}_{2}\right), 6.91(2 \mathrm{H}, \mathrm{s}, 2-\mathrm{H}, 5-\mathrm{H})$. Anal. Calcd. for $\mathrm{C}_{14} \mathrm{H}_{18} \mathrm{I}_{2} \mathrm{O}_{5}(520.10)$ : C, 32.33; H, 3.49; I, 48,80. Found: C, 32.52; H, 3.27\%.

3,3'(4')-Diiododibenzo-18-crown-6 (2+3). A mixture of iodine $(2.1 \mathrm{~g}, 8.4 \mathrm{mmol})$ and $\mathrm{HIO}_{3}$ $(1.5 \mathrm{~g}, 8.5 \mathrm{mmol})$ was slowly added in portions to a stirred solution of dibenzo-18-crown-6 $(4.2 \mathrm{~g}, 10 \mathrm{mmol})$ in a mixture of $80 \%$ acetic acid $(40 \mathrm{~mL})$ and $30 \%$ sulfuric acid $(5 \mathrm{~mL})$. The reaction mixture was stirred to its discoloration during $2 \mathrm{~h}$ at $50-55{ }^{\circ} \mathrm{C}$, and then cold water $(300 \mathrm{~mL})$ was added. The solution was washed with $30 \% \mathrm{Na}_{2} \mathrm{SO}_{3}$ aq. and extracted with $\mathrm{CHCl}_{3}$ $(3 \times 100 \mathrm{~mL})$, and the organic layer dried on $\mathrm{Na}_{2} \mathrm{SO}_{4}$, filtered through a $\mathrm{SiO}_{2}$ bed $(2.5 \times 2 \mathrm{~cm})$. The solvent was removed in vacuo and the residue was recrystallized from toluene. The yield of mixture of cis- and trans- isomers (2+3) was $5.6 \mathrm{~g}(83 \%), \mathrm{mp} 176-180{ }^{\circ} \mathrm{C} ; 1 \mathrm{H} \mathrm{NMR}: \delta\left(\mathrm{CDCl}_{3}\right)$ 3.94-4.07 (8H, m, $\left.2 \mathrm{CH}_{2} \mathrm{OCH}_{2}\right), 4.09-4.22\left(8 \mathrm{H}, \mathrm{m}, 4 \mathrm{ArOCH}_{2}\right), 6.62\left(2 \mathrm{H}, \mathrm{d}, 4-\mathrm{H}, 12(15)-\mathrm{H},{ }^{2} J=\right.$ 
8.1 Hz), $7.13(2 \mathrm{H}, \mathrm{c}, 1-\mathrm{H}, 15(12)-\mathrm{H}), 7.21\left(2 \mathrm{H}, \mathrm{d}, 3-\mathrm{H}, 13(14)-\mathrm{H},{ }^{2} J=8.1 \mathrm{~Hz}\right)$. Anal. Calcd. for $\mathrm{C}_{20} \mathrm{H}_{22} \mathrm{I}_{2} \mathrm{O}_{6}$ (612.19):C, 39.24; H, 3.62; I, 41.46. Found: C, 39.72; H, 3.39\%.

3,4,3',4'-Tetraiododibenzo-18-crown 6 (4). A mixture of iodine (4.3 g, $16.9 \mathrm{mmol})$ and $\mathrm{HIO}_{3}$ (2.1 g, $11.9 \mathrm{mmol})$ was slowly added by portions to stirred solution of dibenzo-18-crown-6 $(4.2 \mathrm{~g}, 10 \mathrm{mmol})$ in a mixture of dioxane $(40 \mathrm{~mL})$ and $30 \%$ sulfuric acid $(10 \mathrm{~mL})$. The reaction mixture was stirred to its discoloration during $2 \mathrm{~h}$ at $50-55{ }^{\circ} \mathrm{C}$, and then cold water $(300 \mathrm{~mL})$ was added. The resulting brown precipitate was filtered, washed with water $(20 \mathrm{~mL})$, dried in air, and recrystallized from DMF. The yield of the compound 4 was $2.9 \mathrm{~g}(63 \%)$; mp $237-239{ }^{\circ} \mathrm{C}$. 1H NMR data: $\delta\left(\mathrm{CD}_{3}\right)_{2} \mathrm{SO} 3.78-3.85\left(8 \mathrm{H}, \mathrm{m}, 2 \mathrm{CH}_{2} \mathrm{OCH}_{2}\right), 3.98-4.05\left(8 \mathrm{H}, \mathrm{m}, 4 \mathrm{ArOCH}_{2}\right), 7.31$ (4H, s, 2-H, 5-H, 2'-H, 15-H). Anal. Calcd. for $\mathrm{C}_{20} \mathrm{H}_{20} \mathrm{I}_{4} \mathrm{O}_{6}$ (863.9):C, 27.80; H, 2.33; I, 58.75. Found: C, 27.62; H, 2.29\%.

3,3'-Diiododibenzo-18-crown-6 (2). Amine 2b (1.6 g, $4.1 \mathrm{mmol})$ in a mixture of water (10 mL), ice $(10 \mathrm{~g})$ and $\mathrm{H}_{2} \mathrm{SO}_{4}(2 \mathrm{~mL})$ was denitrated by a cold solution of $\mathrm{NaNO}_{2}(0.7 \mathrm{~g}, 10.1 \mathrm{mmol}$ in 5 $\left.\mathrm{mL} \mathrm{H}_{2} \mathrm{O}\right)$ at $0+5{ }^{\circ} \mathrm{C}$. Sulfuric acid $(5 \mathrm{~mL})$ was added after $20 \mathrm{~min}$ and the solution obtained was slowly added to a cold solution of aqueous $\mathrm{KI}(2.0 \mathrm{~g}, 12 \mathrm{mmol}$ in $5 \mathrm{~mL})$ containing $\mathrm{Cu}^{0}(0.5 \mathrm{~g}$, $7.8 \mathrm{mmol})$, and the reaction mass carefully heated on a hot-water bath $\left(65-70{ }^{\circ} \mathrm{C}\right)$ until nitrogen gas liberation stopped. The solution was extracted with $\mathrm{CHCl}_{3}(3 \times 100 \mathrm{~mL})$, washed with water, and then $30 \% \mathrm{Na}_{2} \mathrm{SO}_{3}$ aq., and the organic layer dried over $\mathrm{Na}_{2} \mathrm{SO}_{4}$, and filtered through $\mathrm{SiO}_{2^{-}}$ bed $(2.5 \times 2 \mathrm{~cm})$. The solvent was removed in vacuo and the residue was recrystallized from benzene. The yield of compound 2 was $0.8 \mathrm{~g}(32 \%), \mathrm{mp} 231-232{ }^{\circ} \mathrm{C}$. Anal. Calcd. for $\mathrm{C}_{20} \mathrm{H}_{22} \mathrm{I}_{2} \mathrm{O}_{6}$ (612.19): C, 39.24; H, 3.62; I, 41.46. Found: C, 39.37; H, 3.69\%. The NMR ${ }^{1} \mathrm{H}$ and IR spectra are given in the Table.

3,4'-Diiododibenzo-18-crown-6 (3). According to the procedure above, the denitration of amine 3b (1.2 g, $3.9 \mathrm{mmol})$ was carried out by using $\mathrm{NaNO}_{2}(0.6 \mathrm{~g}, 8.7 \mathrm{mmol})$, KI (1.6 g, $\left.9.6 \mathrm{mmol}\right)$ and $\mathrm{Cu}^{\circ}(0.5 \mathrm{~g}, 7.8 \mathrm{mmol})$; the purification by column chromatography resulted in $0.8 \mathrm{~g}(42 \%)$ of compound 3, mp $189-191{ }^{\circ} \mathrm{C}$ (from benzene-hexane). Anal. Calcd. for $\mathrm{C}_{20} \mathrm{H}_{22} \mathrm{I}_{2} \mathrm{O}_{6}$ (612.19): C, 39.24; H, 3.62; I, 41.46. Found: C, 39.37; H, 3.69; I, 41.73\%. The ${ }^{1} \mathrm{H}-\mathrm{NMR}$ and IR spectra are given in the Table.

3,4-bis-(Trimethylsilanylethynyl)benzo-15-crown-5 (6a). A mixture of iodide (1) (0.5, 1 $\mathrm{mmol})$ and the acetylene 5a $(0.4 \mathrm{~mL}, 2.8 \mathrm{mmol})$ in the presence of $\mathrm{PdCl}_{2}\left(\mathrm{PPh}_{3}\right)_{2}(15 \mathrm{mg}, 0.021$ $\mathrm{mmol})$ and $\mathrm{CuI}(7.5 \mathrm{mg}, 0.075 \mathrm{mmol})$ in $\mathrm{Et}_{3} \mathrm{~N}(1 \mathrm{~mL})$ and benzene $(10 \mathrm{~mL})$ was stirred at $75-$ $80{ }^{\circ} \mathrm{C}$ for $0.5 \mathrm{~h}$. Finally, the mixture was filtered through a $\mathrm{SiO}_{2}$ column $(2.5 \times 2 \mathrm{~cm})$ and evaporated in vacuo, and the residue was recrystallized from a mixture of benzene-hexane. The yield of compound $6 \mathbf{a}$ was $0.36 \mathrm{~g}(87.7 \%), \mathrm{mp} 97-99{ }^{\circ} \mathrm{C}$. IR $(\mathrm{KBr}): v\left[\mathrm{~cm}^{-1}\right] 2152(\mathrm{C} \equiv \mathrm{C}) .1 \mathrm{H}$ NMR data: $\delta\left(\mathrm{CDCl}_{3}\right) 0.26\left(18 \mathrm{H}, \mathrm{s}, 2 \mathrm{Si}\left(\mathrm{CH}_{3}\right)_{3}\right) ; 3.83\left(8 \mathrm{H}, \mathrm{s}, 4 \mathrm{OCH}_{2}\right) ; 3.86-3.93(4 \mathrm{H}, \mathrm{m}, 2$ $\left.\mathrm{ArOCH}_{2} \underline{\mathrm{CH}}_{2}\right) ; 4.08-4.17$ (4 H, s, $\left.2 \mathrm{ArOCH}_{2} \mathrm{CH}_{2}\right) ; 6.91$ (2 H, s, 2-H, 5-H). MS, m/z, \%: 460.0 $[\mathrm{M}]^{+}$(100), 372.0 (9), 328.0 (18), 312.9 (38), 73.0 (54). Calcd. for $\mathrm{C}_{24} \mathrm{H}_{36} \mathrm{O}_{5} \mathrm{Si}_{2} \mathrm{M}=460.2161$. Found: $m / z 460.2100[\mathrm{M}]^{+}$.

3,3'(4')-bis-(Trimethylsilylethynyl)dibenzo-18-crown-6 (7+8)a. From the mixture of iodides $(\mathbf{2}+\mathbf{3})(2.5 \mathrm{~g}, 4.2 \mathrm{mmol})$ and the acetylene $\mathbf{5 a}(1.3 \mathrm{~mL}, 9.3 \mathrm{mmol})$ in the presence of $\mathrm{PdCl}_{2}\left(\mathrm{PPh}_{3}\right)_{2}$ 
(90 $\mathrm{mg}, 0.129 \mathrm{mmol}$ ), CuI (45 mg, $0.45 \mathrm{mmol})$, a mixture of the compounds $(7+8) \mathbf{a}, 1.6 \mathrm{~g}$ (69.6\%), m.p. $181-184.5{ }^{\circ} \mathrm{C}$ was synthesized as above. IR $(\mathrm{KBr}): v\left[\mathrm{~cm}^{-1}\right] 2143(\mathrm{C} \equiv \mathrm{C}) .1 \mathrm{H}$ NMR: $\delta\left(\mathrm{CDCl}_{3}\right) 0.28\left(18 \mathrm{H}, \mathrm{s}, 2 \mathrm{Si}\left(\mathrm{CH}_{3}\right)_{3}\right), 4.03-4.05\left(8 \mathrm{H}, \mathrm{m}, 2 \mathrm{CH}_{2} \mathrm{OCH}_{2}\right) ; 4.17-4.19(8 \mathrm{H}$, m, $\left.4 \mathrm{ArOCH}_{2}\right) ; 6.78$ (2 H, d, 5-H, 5'(2')-H, $J=8.2$ ), 6.98 (2 H, d, 2-H, 2'(5')-H, $\left.J=2.5\right), 7.08$ (2 $\mathrm{H}$, dd, 4-H, 4'(3')-H, $\left.{ }^{1} J=8.2,{ }^{2} J=2.5\right)$. Anal. Calcd. for $\mathrm{C}_{30} \mathrm{H}_{40} \mathrm{O}_{6} \mathrm{Si}_{2}(552.81): \mathrm{C}, 65.18 ; \mathrm{H}, 7.29$. Found: C, 65.21; H, 7.09\%.

3,3'-bis-(Trimethylsilylethynyl)dibenzo-18-crown-6 (7a). A mixture of iodide (2) (0.63g, 1 $\mathrm{mmol})$, acetylene $5 \mathbf{a}(0.4 \mathrm{~mL}, 3.1 \mathrm{mmol})$ in the presence of $\mathrm{PdCl}_{2}\left(\mathrm{PPh}_{3}\right)_{2}(30 \mathrm{mg}, 0.043 \mathrm{mmol})$ and $\mathrm{CuI}(15 \mathrm{mg}, 0.15 \mathrm{mmol})$ in $\mathrm{Et}_{3} \mathrm{~N}(2 \mathrm{~mL})$ and benzene $(10 \mathrm{~mL})$ was stirred at $75-80{ }^{\circ} \mathrm{C}$ for $0.25 \mathrm{~h}$. Finally, the mixture was filtered through a $\mathrm{SiO}_{2}$ column $(2.5 \mathrm{x} 2 \mathrm{~cm})$ and evaporated in vacuo, and the residue was recrystallized from a mixture of benzene-hexane. The yield of compound 7a was $0.2 \mathrm{~g} \mathrm{(40 \% ),} \mathrm{mp} \mathrm{176-178}{ }^{\circ} \mathrm{C}$. Anal. Calcd. for $\mathrm{C}_{30} \mathrm{H}_{40} \mathrm{O}_{6} \mathrm{Si}_{2}$ (552.81): $\mathrm{C}, 65.18$; H, 7.29. Found: C, 65.31; H, 7.63\%. The ${ }^{1} \mathrm{H}-\mathrm{NMR}$ and IR spectra are given in the Table.

3,4'-bis-(Trimethylsilylethynyl)dibenzo-18-crown-6 (8a). A mixture of iodide (3) (0.65 g, 1 $\mathrm{mmol})$ and the acetylene $5 \mathbf{a}(0.4 \mathrm{~mL}, 3.1 \mathrm{mmol})$ in the presence of $\mathrm{PdCl}_{2}\left(\mathrm{PPh}_{3}\right)_{2}(30 \mathrm{mg}, 0.043$ $\mathrm{mmol})$ and $\mathrm{CuI}(15 \mathrm{mg}, 0.15 \mathrm{mmol})$ in $\mathrm{Et}_{3} \mathrm{~N}(2 \mathrm{~mL})$ and benzene $(10 \mathrm{~mL})$ was stirred at $75-$ $80{ }^{\circ} \mathrm{C}$ for $0.25 \mathrm{~h}$. Finally, the mixture was filtered through a $\mathrm{SiO}_{2}$ column $(2.5 \mathrm{x} 2 \mathrm{~cm})$ and evaporated in vacuo, and the residue was recrystallized from a mixture of benzene-hexane. The yield of compound 8a was $0.24 \mathrm{~g}(41 \%)$, mp 191-193 ${ }^{\circ} \mathrm{C}$. Anal. Calcd. for $\mathrm{C}_{30} \mathrm{H}_{40} \mathrm{O}_{6} \mathrm{Si}_{2}$ (552.81):C, 65.18; H, 7.29. Found: C, 64.91; H, 7.55\%. The ${ }^{1} \mathrm{H}-\mathrm{NMR}$ and IR spectra are given in the Table.

3,4,3',4'-tetrakis-(Trimethylsilylethynyl)dibenzo-18-crown-6 (9a). A mixture of the iodide (4) $(0.5 \mathrm{~g}, 0.5 \mathrm{mmol})$ and the acetylene $5 \mathbf{a}(0.4 \mathrm{~mL}, 3.1 \mathrm{mmol})$ in the presence of $\mathrm{PdCl}_{2}\left(\mathrm{PPh}_{3}\right)_{2}(30$ $\mathrm{mg}, 0.043 \mathrm{mmol})$ and $\mathrm{CuI}(15 \mathrm{mg}, 0.15 \mathrm{mmol})$ in $\mathrm{Et}_{3} \mathrm{~N}(2 \mathrm{~mL})$ and benzene $(10 \mathrm{~mL})$ was stirred at $75-80{ }^{\circ} \mathrm{C}$ for $0.25 \mathrm{~h}$. Finally, the mixture was filtered through a $\mathrm{SiO}_{2}$ column $(2.5 \times 2 \mathrm{~cm})$ and evaporated under reduced pressure. The residue was recrystallized from benzene-hexane mixture. The yield of compound 9a was $0.13 \mathrm{~g}(40.2 \%), \mathrm{mp} \mathrm{98-100}{ }^{\circ} \mathrm{C}$. IR (KBr): $v$ [cm $\left.{ }^{-1}\right] 2154$ $(\mathrm{C} \equiv \mathrm{C})$. 1H NMR data: $\delta\left(\mathrm{CDCl}_{3}\right) 0.31\left(36 \mathrm{H}, \mathrm{s}, 4 \mathrm{Si}\left(\mathrm{CH}_{3}\right)_{3}\right), 4.01-4.03\left(8 \mathrm{H}, \mathrm{m}, 2 \mathrm{CH}_{2} \mathrm{OCH}_{2}\right)$; 4.17-4.18 (8 H, m, $\left.4 \mathrm{ArOCH}_{2}\right)$; $6.91(4-\mathrm{H}, \mathrm{s}, 2-\mathrm{H}, 5-\mathrm{H}, 5$ '-H, 2'-H). Anal. Calcd. for $\mathrm{C}_{40} \mathrm{H}_{56} \mathrm{O}_{6} \mathrm{Si}_{4}$ (745.21):C, 64.47; H, 7.57. Found: C, 64.11; H, 7.29\%.

3,4-bis-(p-Ethynylbenzaldehyde)benzo-15-crown-5 (6b). Route A (Scheme 3). A mixture of iodide (1) $(0.9 \mathrm{~g}, 1.7 \mathrm{mmol})$, acetylene $5 \mathbf{b}(0.4 \mathrm{~g}, 3.1 \mathrm{mmol})$ in the presence of $\mathrm{Pd}(\mathrm{OAc})_{2}(20 \mathrm{mg}$, $0.089 \mathrm{mmol})$ and $\mathrm{CuI}(15 \mathrm{mg}, 0.15 \mathrm{mmol}), \mathrm{PPh}_{3}(60 \mathrm{mg}, 0.228 \mathrm{mmol})$ in $\mathrm{Et}_{3} \mathrm{~N}(7 \mathrm{~mL})$ and benzene $(15 \mathrm{~mL})$ was stirred at $75-80{ }^{\circ} \mathrm{C}$ for $0.25 \mathrm{~h}$. Finally, the mixture was filtered through a $\mathrm{SiO}_{2}$ column $(2.5 \times 2 \mathrm{~cm})$ and evaporated in vacuo, and the residue was purified by column chromatography and then recrystallized from benzene-hexane mixture. The yield of compound 6b was $0.69 \mathrm{~g}(76.7 \%)$.

Route B (Scheme 4). A mixture of the acetylene (6) $(0.1 \mathrm{~g}, 0.3 \mathrm{mmol})$, 4-bromobenzaldehyde 13 $(0.14 \mathrm{~g}, 0.7 \mathrm{mmol})$ in presence of $\mathrm{Pd}(\mathrm{OAc})_{2}(10 \mathrm{mg}, 0.044 \mathrm{mmol})$ and $\mathrm{CuI}(5 \mathrm{mg}, 0.026 \mathrm{mmol})$, $\mathrm{PPh}_{3}(30 \mathrm{mg}, 0.114 \mathrm{mmol})$ in $\mathrm{Et}_{3} \mathrm{~N}(2 \mathrm{~mL})$ and benzene $(10 \mathrm{~mL})$ was stirred at $75-80{ }^{\circ} \mathrm{C}$ for 0.25 
h. Finally, the mixture was filtered through a $\mathrm{SiO}_{2}$ column $(2.5 \times 2 \mathrm{~cm})$ and evaporated in vacuo, and the residue was purified by column chromatography and then recrystallized from benzene. The yield of compound $\mathbf{6 b}$ was $0.08 \mathrm{~g}(62.5 \%)$; mp 156-157 ${ }^{\circ} \mathrm{C}$. IR $(\mathrm{KBr}): v\left[\mathrm{~cm}^{-1}\right] 1697(\mathrm{C}=\mathrm{O})$, $2204(\mathrm{C} \equiv \mathrm{C})$. 1H- NMR data: $\delta\left(\mathrm{CDCl}_{3}\right) 3.69\left(8 \mathrm{H}, \mathrm{s}, 4 \mathrm{OCH}_{2}\right) ; 3.86-3.95(4 \mathrm{H}, \mathrm{m}, 2$ $\left.\mathrm{ArOCH}_{2} \underline{\mathrm{CH}}_{2}\right)$; 4.15-4.22 (4 H, m, $\left.2 \mathrm{ArOCH}_{2} \mathrm{CH}_{2}\right)$; 7.08 (2 H, s, 2-H, 5-H), 7.69 (4 H, d, 2,2'-H, 2,6'-H, $J=8.2$ ), 7.89 (4 H, d, 2,3'-H, 2,5'-H, $J=8.2$ ), 10.05 (2 H, s, CHO). Anal. Calcd. for $\mathrm{C}_{32} \mathrm{H}_{28} \mathrm{O}_{7}$ (524.56): C, 73.27; H, 5.38. Found: C, 73.14; H, 5.45\%.

3,3'(4')-bis-(p-Ethynylbenzaldehyde)dibenzo-18-crown-6 (7+8)b. Route A (Scheme 3). The compounds mixture $(\mathbf{7 + 8}) \mathbf{b}, 0.79 \mathrm{~g}(52.3 \%)$ was prepared from a mixture of the compounds $(\mathbf{2}+\mathbf{3})(1.5 \mathrm{~g}, 2.4 \mathrm{mmol})$, p-ethynylbenzaldehyde $\mathbf{5 b}(0.78 \mathrm{~g}, 5.9 \mathrm{mmol})$ in the presence of $\mathrm{Pd}(\mathrm{OAc})_{2}(20 \mathrm{mg}, 0.089 \mathrm{mmol}), \mathrm{CuI}(10 \mathrm{mg}, 0.0520 \mathrm{mmol}), \mathrm{PPh}_{3}(60 \mathrm{mg}, 0.228 \mathrm{mmol}) \mathrm{in} \mathrm{NEt}_{3}$ $(10 \mathrm{~mL})$ and benzene $(15 \mathrm{~mL})$.

Route B (Scheme 4). The mixture of (7+8)b $0.9 \mathrm{~g}$ (52.9\%), mp 147-154 (toluene) was prepared from a mixture of the compounds $(\mathbf{1 0}+\mathbf{1 1})(1.1 \mathrm{~g}, 2.7 \mathrm{mmol}), p$-bromobenzaldehyde 13 (1.2 $\mathrm{g}$, $6.7 \mathrm{mmol})$ in the presence of $\mathrm{Pd}(\mathrm{OAc})_{2}(20 \mathrm{mg}, 0.089 \mathrm{mmol}), \mathrm{CuI}(10 \mathrm{mg}, 0.052 \mathrm{mmol}), \mathrm{PPh}_{3}$ $(60 \mathrm{mg}, 0.228 \mathrm{mmol})$ in $\mathrm{NEt}_{3}(10 \mathrm{~mL})$ and benzene $(15 \mathrm{~mL}) . \mathrm{IR}(\mathrm{KBr}): v\left[\mathrm{~cm}^{-1}\right] 1653(\mathrm{C}=\mathrm{O})$, $2201(\mathrm{C} \equiv \mathrm{C})$. 1H NMR data: $\delta\left(\mathrm{CDCl}_{3}\right)$ 3.91-3.94 (8 H, m, $\left.2 \mathrm{CH}_{2} \mathrm{OCH}_{2}\right) ; 4.16-4.19(8 \mathrm{H}, \mathrm{m}, 4$ $\left.\mathrm{ArOCH}_{2}\right) ; 7.02$ (2 H, d, 5-H, 5(2')-H, $\left.J=8.4\right)$; 7.23 (2 H, s, 2-H, 2'(5')-H; 7.27 (2 H, d, 4-H, 4'(3')-H, $J=8.4$ ); 7.65 (4 H, d, 2 2'-H, 2,6'-H, $J=8.2$ ); 7.87 (4 H, d, 2,3'-H, 2,5'-H, J = 8.2); 10.04 (2 H, s, 2 CHO). Anal. Calcd. for $\mathrm{C}_{38} \mathrm{H}_{32} \mathrm{O}_{8}$ (616.66): C, 74.01; H, 5.23. Found: C, 74.21; $\mathrm{H}, 5.28 \%$.

3,4,3',4'-tetrakis(p-Ethynylbenzaldehyde)-18-crown-6 (9b). Route A (Scheme 3). The compound (9b) (0.9 g, 89.1\%), mp 223-225 (toluene) was prepared from the compound (4) (1 g, $1.3 \mathrm{mmol}), p$-ethynylbenzaldehyde $5 \mathbf{b}(0.9 \mathrm{~g}, 0.7 \mathrm{mmol})$ in the presence of $\mathrm{Pd}(\mathrm{OAc})_{2}(20 \mathrm{mg}$, $0.089 \mathrm{mmol})$, CuI (10 mg, $0.0520 \mathrm{mmol}), \mathrm{PPh}_{3}(60 \mathrm{mg}, 0.228 \mathrm{mmol})$ in $\mathrm{NEt}_{3}(10 \mathrm{~mL})$ and benzene $(15 \mathrm{~mL})$. IR $(\mathrm{KBr}): v\left[\mathrm{~cm}^{-1}\right] 1698(\mathrm{C}=\mathrm{O}), 2203(\mathrm{C} \equiv \mathrm{C})$. $1 \mathrm{H}$ NMR data: $\delta\left(\mathrm{CDCl}_{3}\right) 3.89-$ 3.95 (8 H, m, $\left.2 \mathrm{CH}_{2} \mathrm{OCH}_{2}\right)$; 4.17-4.18 (8 H, m, $\left.4 \mathrm{ArOCH}_{2}\right)$; 7.28 (4 H, s, 2-H, 5-H, 5'-H, 2'-H); 7.68 (8 H, d, 4,2'-H, 6'-H, $J=8.2$ ); 7.88 (8 H, d, 4,3'-H, 5'-H, $J=8.2)$; 10.04 (4 H, s, 4 CHO). Anal. Calcd. for $\mathrm{C}_{56} \mathrm{H}_{40} \mathrm{O}_{10}(872.91)$ : C, 77.05; H, 4.62. Found: C, 77.21; H, 5.28\%.

3,4-bis-(3-Hydroxy-3-methylbut-1-ynyl)benzo-15-crown-5 (6c). A mixture of iodide 1 (0.5, 1 $\mathrm{mmol})$, and the acetylene $5 \mathbf{c}(0.23 \mathrm{~mL}, 2.5 \mathrm{mmol})$ in the presence of $\mathrm{PdCl}_{2}\left(\mathrm{PPh}_{3}\right)_{2}(15 \mathrm{mg}, 0.021$ $\mathrm{mmol})$ and $\mathrm{CuI}(7.5 \mathrm{mg}, 0.075 \mathrm{mmol})$ in $\mathrm{Et}_{3} \mathrm{~N}(1 \mathrm{~mL})$ and benzene $(15 \mathrm{~mL})$ was stirred at $75-$ $80{ }^{\circ} \mathrm{C}$ for $2.5-3 \mathrm{~h}$. Finally, the mixture was filtered through a $\mathrm{SiO}_{2}$ bed in a column $(2.5 \times 2 \mathrm{~cm})$ and evaporated in vacuo, and the residue was recrystallized from benzene. The yield of compound 6c was $0.2 \mathrm{~g}(48.8 \%)$, mp 103-105 ${ }^{\circ} \mathrm{C}$. IR (KBr): $v\left[\mathrm{~cm}^{-1}\right] 2200(\mathrm{C} \equiv \mathrm{C}) ; 3222$ (br., $\mathrm{OH})$. 1H NMR data: $\left.\delta\left(\mathrm{CD}_{3}\right)_{2} \mathrm{SO}\right) 1.18\left(12 \mathrm{H}, \mathrm{s}, 2 \mathrm{C}\left(\mathrm{CH}_{3}\right)_{2}\right)$; 3.76-3.81 (8 H, m, $\left.4 \mathrm{OCH}_{2}\right)$; 3.893.95 (4 H, m, $\left.2 \mathrm{ArOCH}_{2} \underline{\mathrm{CH}}_{2}\right)$; 4.10-4.20 (4 H, m, $\left.2 \mathrm{ArOCH}_{2} \mathrm{CH}_{2}\right) ; 6.89$ (2 H, s, 1-H, 4-H). Anal. Calcd. for $\mathrm{C}_{24} \mathrm{H}_{32} \mathrm{O}_{7}(432,51): \mathrm{C}, 66.65 ; \mathrm{H}, 7.46$. Found: C, 66.52; H, 7.39\%.

3,3'(4')-bis-(3-Hydroxy-3-methylbut-1-ynyl)dibenzo-18-crown-6 (7+8)c. A mixture of iodides $(\mathbf{2}+\mathbf{3})(1 \mathrm{~g}, 1.5 \mathrm{mmol})$, and carbinol $\mathbf{5 c}(0.3 \mathrm{~mL}, 3.3 \mathrm{mmol})$ in the presence of 
$\mathrm{PdCl}_{2}\left(\mathrm{PPh}_{3}\right)_{2}(30 \mathrm{mg}, 0.043 \mathrm{mmol})$ and $\mathrm{CuI}(15 \mathrm{mg}, 0.15 \mathrm{mmol})$ in $\mathrm{Et}_{3} \mathrm{~N}(2 \mathrm{~mL})$ and benzene (10 $\mathrm{mL}$ ) was stirred at $75-80{ }^{\circ} \mathrm{C}$ for $2.5-3 \mathrm{~h}$. Finally, the mixture was filtered through a $\mathrm{SiO}_{2}$ column $(2.5 \times 2 \mathrm{~cm})$ and evaporated in vacuo, and the residue was recrystallized from mixture of benzenehexane. The yield of the mixed compounds $(7+8) \mathrm{c}$ was $0.75 \mathrm{~g}(86.2 \%)$, mp 87-91 ${ }^{\circ} \mathrm{C}$. IR $(\mathrm{KBr})$ : $v\left[\mathrm{~cm}^{-1}\right] 2223(\mathrm{C} \equiv \mathrm{C}) ; 3374$ (br., $\left.\mathrm{OH}\right) .1 \mathrm{H} \mathrm{NMR}$ data: $\delta\left(\mathrm{CD}_{3}\right) \mathrm{SO} 1.57\left(12 \mathrm{H}, \mathrm{s}, 2 \mathrm{C}\left(\mathrm{CH}_{3}\right)_{2}\right)$; 3.984.05 (8 H, m, $\left.4 \mathrm{OCH}_{2}\right)$; 4.17-4.18 (4 H, m, $\left.2 \mathrm{ArOCH}_{2} \underline{\mathrm{CH}}_{2}\right)$; 6.79 (2 H, d, 5-H, 5'(2')-H, J= 8.2); 6.93 (2 H, s, 2-H, 2'(5')-H); 7.02 (2 H, d, 4-H, 4'(3')-H, $J=8.2$ ). Anal. Calcd. for $\mathrm{C}_{30} \mathrm{H}_{36} \mathrm{O}_{8}$ (524.60): C, 68.68; H, 6.92. Found: C, 68.6166.52; H, 7.09\%.

3,4-Diethynylbenzo-15-crown-5 (6). Procedure iii (Scheme 3). The compound 6a (0.24 g, 0.5 mmol) was treated with a $10 \%$ solution of $\mathrm{KOH}$ in methanol $(15 \mathrm{~mL})$. The yield of the compound 6 was $0.1 \mathrm{~g}(60 \%), \mathrm{mp} 109-110{ }^{\circ} \mathrm{C}$. Procedure iv (Scheme 3). A mixture of 6c $(0.2 \mathrm{~g}, 0.48 \mathrm{mmol})$ and powdered $\mathrm{KOH}(0.1 \mathrm{~g}, 1.7 \mathrm{mmol})(20 \mathrm{~mL})$ was boiled in dry benzene for 2.5-3 h. Finally, the mixture was filtered through a $\mathrm{SiO}_{2}$ column $(2.5 \times 2 \mathrm{~cm})$ and evaporated in vacuo. The residue was recrystallized from benzene-hexane mixture. The yield of compound 6 was $0.03 \mathrm{~g}(20 \%)$.

IR (KBr): $v\left[\mathrm{~cm}^{-1}\right] 2120(\mathrm{C} \equiv \mathrm{C}) ; 3219,3277(\mathrm{C} \equiv \mathrm{CH}) .1 \mathrm{H} \mathrm{NMR}: \delta\left(\mathrm{CDCl}_{3}\right) 3.26(2 \mathrm{H}, \mathrm{s}, 2$ $\mathrm{C} \equiv \mathrm{CH}) ; 3.69-3.82\left(8 \mathrm{H}, \mathrm{m}, 4 \mathrm{OCH}_{2}\right) ; 3.85-3.97\left(4 \mathrm{H}, \mathrm{m}, 2 \mathrm{ArOCH}_{2} \underline{\mathrm{CH}}_{2}\right) ; 4.14$ (4 H, s, 2 $\mathrm{ArOCH}_{2} \mathrm{CH}_{2}$ ); 6.97 (2 H, s, 2-H, 5-H). MS, m/z, \%: $316.20[\mathrm{M}]^{+}$(21), 228.2 (11), 184.1 (90), 128.1 (12), 45.1 (10). Calcd. for $\mathrm{C}_{18} \mathrm{H}_{20} \mathrm{O}_{5}: \mathrm{M}=316.13292$. Found: $m / z 316.0234[\mathrm{M}]^{+}$.

3,3'(4')-Diethynyldibenzo-18-crown-6 (10+11) Procedure iii (Scheme 3). The compounds $(7+8) \mathbf{a}(0.3 \mathrm{~g}, 5.4 \mathrm{mmol})$ were treated with a $10 \%$ solution of $\mathrm{KOH}$ in methanol $(15 \mathrm{~mL})$ at room temperature during $1-1.5 \mathrm{~h}$. The yield of the compounds $\mathbf{1 0}+\mathbf{1 1}$ was $0.06 \mathrm{~g}(27.3 \%)$; $\mathrm{mp}$ $141-145^{\circ} \mathrm{C}$. Procedure $i v$ (Scheme 3). A mixture of $(\mathbf{7}+\mathbf{8}) \mathbf{c}(1.6 \mathrm{~g}, 3 \mathrm{mmol})$ and powdered $\mathrm{KOH}$ $(0.4 \mathrm{~g}, 8 \mathrm{mmole})$ was boiled in dry toluene $(45 \mathrm{~mL})$ for $2.5-33 \mathrm{~h}$. Finally, the mixture was filtered through an $\mathrm{SiO}_{2}$ column $(2.5 \times 2 \mathrm{~cm})$ and evaporated in vacuo. The residue was purified by column chromatography and recrystallized from benzene-hexane mixture. The yield of compounds $(\mathbf{1 0}+\mathbf{1 1})$ was $0.2 \mathrm{~g}(16.7 \%)$.

IR (KBr): $v\left[\mathrm{~cm}^{-1}\right] 2101(\mathrm{C} \equiv \mathrm{C}) ; 3288(\mathrm{C} \equiv \mathrm{CH}) .1 \mathrm{H} \mathrm{NMR:} \delta\left(\mathrm{CDCl}_{3}\right) 3.02(2 \mathrm{H}, \mathrm{s}, 2 \mathrm{C} \equiv \mathrm{CH})$, 4.06-4.17 (8 H, m, $\left.2 \mathrm{CH}_{2} \mathrm{OCH}_{2}\right)$; 4.18-4.21 (8 H, m, $\left.4 \mathrm{ArOCH}_{2}\right)$; 6.81 (2 H, d, 5-H, 5'(2')-H, $J$ = 8.5); 7.01 (2 H, d, 2-H, 2'(5')-H, $J=2.3)$; 7.11 (2 H, dd, 4-H, 4'(3')-H, $\left.{ }^{1} J=8.5,{ }^{2} J=2.3\right)$. Anal. Calcd. for $\mathrm{C}_{24} \mathrm{H}_{24} \mathrm{O}_{6}$ (408.44):C, 70.57, 5.93. Found: C, 70.81.11; H, 5.87\%.

3,3'-Di-ethynyldibenzo-18-crown-6 (10). Procedure iii (Scheme 3). The compound 7a (0.2 g, $0.36 \mathrm{mmol})$ was treated with $\mathrm{K}_{2} \mathrm{CO}_{3}(0.15 \mathrm{~g}, 1 \mathrm{mmol})$ solution in methanol $(7 \mathrm{~mL})$ at room temperature for $1-1.5 \mathrm{~h}$. The yield of the compound 10 was $0.1 \mathrm{~g}(68 \%)$; mp $192-194{ }^{\circ} \mathrm{C}$. Anal. Calcd. for $\mathrm{C}_{24} \mathrm{H}_{24} \mathrm{O}_{6}$ (408.44):C, 70.57, 5.93. Found: C, 70.24; H, 5.86\%. The ${ }^{1} \mathrm{H}$ NMR and IR spectra are given in the Table.

3,4'-Diethynyldibenzo-18-crown-6 (11). Procedure ii (Scheme 3). The compound 8a (0.2 g, $0.36 \mathrm{mmol})$ was treated with $\mathrm{K}_{2} \mathrm{CO}_{3}(0.15 \mathrm{~g}, 1 \mathrm{mmol})$ solution in methanol $(7 \mathrm{~mL})$ at room temperature for $1-1.5 \mathrm{~h}$. The yield of compound 10 was $0.1 \mathrm{~g}(68 \%)$; mp $171-173{ }^{\circ} \mathrm{C}$. Anal. 
Calcd. for $\mathrm{C}_{24} \mathrm{H}_{24} \mathrm{O}_{6}$ (408.44): C, 70.57, 5.93. Found: C, 70.33; H, 5.69\%. The ${ }^{1} \mathrm{H}-\mathrm{NMR}$ and IR spectra are given in the Table.

3,4,3',4'-Tetrakis(ethynyl)dibenzo-18-crown-6 (12). Procedure iii (Scheme 3). The compound 9a $(0.15 \mathrm{~g}, 0.2 \mathrm{mmol})$ was treated with $\mathrm{K}_{2} \mathrm{CO}_{3}(0.15 \mathrm{~g}, 1 \mathrm{mmol})$ solution in methanol $(7 \mathrm{~mL})$ at room temperature for $1-1.5 \mathrm{~h}$. The yield of compound 12 was $0.05 \mathrm{~g}(55 \%)$; mp $115-117^{\circ} \mathrm{C}$. IR $(\mathrm{KBr}): v\left[\mathrm{~cm}^{-1}\right] 2141(\mathrm{C} \equiv \mathrm{C}) ; 3278(\mathrm{C} \equiv \mathrm{CH}) .1 \mathrm{H} \mathrm{NMR}$ data: $\delta\left(\mathrm{CDCl}_{3}\right) 3.2(4 \mathrm{H}, \mathrm{s}, 4 \mathrm{C} \equiv \mathrm{CH})$, 4.01-4.03 (8 H, m, $\left.2 \mathrm{CH}_{2} \mathrm{OCH}_{2}\right)$; 4.17 - 4.18 (8 H, m, $\left.4 \mathrm{ArOCH}_{2}\right)$; 6.95 (4 H, s, 2-H, 5-H, 5'-H, 2'-H). Anal. Calcd. for $\mathrm{C}_{28} \mathrm{H}_{24} \mathrm{O}_{6}$ (456.49):C, 73.67, H, 5.30. Found: C, 73.80; H, 5.47\%.

3,4-bis-(3-Diethylaminoprop-1-ynyl)benzo-15-crown-5 (15a). A mixture of the acetylene (6) $(0.08 \mathrm{~g}, 0.25 \mathrm{mmol}),(\mathrm{CHO})_{\mathrm{x}}(0.02 \mathrm{~g}, 0.5 \mathrm{mmol})$ and diethylamine $\mathbf{1 4 a}(0.06 \mathrm{~mL}, 0.5 \mathrm{mmol})$ in the presence of $\mathrm{Cu}(\mathrm{OAc})_{2}(50 \mathrm{mg})$, and $30 \% \mathrm{H}_{2} \mathrm{SO}_{4}(0.1 \mathrm{~mL})$ was stirred in an atmosphere of argon under refluxing in dioxane $(10 \mathrm{~mL})$ at $75-80{ }^{\circ} \mathrm{C}$ for $0.25 \mathrm{~h}$. Finally, the mixture was diluted with water $(40 \mathrm{~mL})$ and extracted with $\mathrm{CHCl}_{3}(3 \times 15 \mathrm{~mL})$. The organic layer was washed with a $15 \%$ solution of $\mathrm{NH}_{4} \mathrm{OH}$, dried under $\mathrm{MgSO}_{4}$, and filtered through a $\mathrm{SiO}_{2}$ column $(2.5 \times 2$ $\mathrm{cm}$ ) and evaporated in vacuo. The residue was purified by column chromatography then recrystallized from benzene-hexane mixture. The yield of the compound 15a was $0.08 \mathrm{~g}(80 \%)$; mp 56-58 ${ }^{\circ} \mathrm{C}$. IR (KBr): $v\left[\mathrm{~cm}^{-1}\right] 2237(\mathrm{C} \equiv \mathrm{C}) .1 \mathrm{H}$ NMR data: $\delta\left(\mathrm{CDCl}_{3}\right) 1.25(12 \mathrm{H}, \mathrm{t}, 4$ $\left.\mathrm{CH}_{2} \underline{\mathrm{CH}}_{3}, J=6.9\right) ; 2.17\left(8 \mathrm{H}, \mathrm{q}, 4 \underline{\mathrm{CH}_{2}} \mathrm{CH}_{3}, J=6.9\right) ; 3.75\left(4 \mathrm{H}, \mathrm{s}, 2 \mathrm{C} \equiv \mathrm{CCH}_{2} \mathrm{~N}\right) ; 3.94-3.89$ (8 $\left.\mathrm{H}, \mathrm{m}, 4 \mathrm{OCH}_{2}\right) ; 4.01-4.06\left(4 \mathrm{H}, \mathrm{m}, 2 \mathrm{ArOCH}_{2} \underline{\mathrm{CH}}_{2}\right) ; 4.14\left(4 \mathrm{H}, \mathrm{s}, 2 \mathrm{ArOCH}_{2} \mathrm{CH}_{2}\right) ; 6.59(2 \mathrm{H}, \mathrm{s}$, 1-H, 4-H). Anal. Calcd. for $\mathrm{C}_{28} \mathrm{H}_{42} \mathrm{~N}_{2} \mathrm{O}_{5}$ (486.64):C, 69.10; H, 7.46; N, 5.76. Found: C, 69.58; H, $7.37 ; \mathrm{N}, 5.62 \%$.

3,4-bis-(3-Morpholinoprop-1-ynyl)benzo-15-crown-5 (15b). The compound 15b $0.07 \mathrm{~g}$ (58.3\%), mp 93-95 ${ }^{\circ} \mathrm{C}$ (from hexane) was prepared from compound 6 (0.08 g, $0.25 \mathrm{mmol}$ ), paraformaldehyde $(0.02 \mathrm{~g}, 0.5 \mathrm{mmol})$, the morpholine $\mathbf{1 4 b}(0.05 \mathrm{~mL}, 0.5 \mathrm{mmol}), \mathrm{Cu}(\mathrm{OAc})_{2}(50$ $\mathrm{mg}), 30 \% \mathrm{H}_{2} \mathrm{SO}_{4}(0.1 \mathrm{~mL})$ in boiling dioxane $(10 \mathrm{~mL})$, as above. $\mathrm{IR}(\mathrm{KBr}): v\left[\mathrm{~cm}^{-1}\right] 2226(\mathrm{C} \equiv \mathrm{C})$. 1H NMR data: $\delta\left(\mathrm{CDCl}_{3}\right)$ 2.53-2.55 (4 H, m, N( $\left.\left.\underline{\mathrm{CH}}_{2} \mathrm{CH}_{2}\right)_{2} \mathrm{O}\right) ; 3.16\left(4 \mathrm{H}, \mathrm{s}, 2 \mathrm{C} \equiv \mathrm{CCH}_{2} \mathrm{~N}\right) ; 3.59-$ $3.62\left(16 \mathrm{H}, \mathrm{m}, 4 \mathrm{OCH}_{2}, 2 \mathrm{~N}\left(\mathrm{CH}_{2} \underline{\mathrm{CH}}_{2}\right)_{2} \mathrm{O}\right) ; 3.65-3.77$ (4 H, m, $\left.2 \mathrm{ArOCH}_{2} \underline{\mathrm{CH}}_{2}\right) ; 4.04$ (4 H, s, 2 $\left.\operatorname{ArOCH}{ }_{2} \mathrm{CH}_{2}\right) ; 6.83$ (2 H, s, 2-H, 5-H). Anal. Calcd. for $\mathrm{C}_{28} \mathrm{H}_{38} \mathrm{~N}_{2} \mathrm{O}_{7}$ (514.61): C, 65.35; H, 7.44; N, 5.44. Found: C, 65.78; H, 7.37; N, 5.42\%.

3,4-bis-(3-Piperidinoprop-1-ynyl)benzo-15-crown-5 (15c). The compound 15c, $0.06 \mathrm{~g}$ (50\%), $\mathrm{mp} 103-105{ }^{\circ} \mathrm{C}$ (from hexane) was prepared from compound $6(0.08 \mathrm{~g}, 0.25 \mathrm{mmol})$, paraformaldehyde $(0.02 \mathrm{~g}, 0.5 \mathrm{mmol})$, piperidine $14 \mathrm{c}(0.05 \mathrm{~mL}, 0.5 \mathrm{mmol}), \mathrm{Cu}(\mathrm{OAc})_{2}(50 \mathrm{mg})$, $30 \% \mathrm{H}_{2} \mathrm{SO}_{4}(0.1 \mathrm{~mL})$ in boiling dioxane $(10 \mathrm{~mL}) . \mathrm{IR}(\mathrm{KBr}): v\left[\mathrm{~cm}^{-1}\right] 2220(\mathrm{C} \equiv \mathrm{C}) .1 \mathrm{H}$ NMR data: $\delta\left(\mathrm{CDCl}_{3}\right)$ 1.41-1.46 (2 H, m, $\left.\left(\mathrm{CH}_{2}\right)_{2} \underline{\mathrm{CH}_{2}}\left(\mathrm{CH}_{2}\right)_{2}\right) ; 1.64\left(4 \mathrm{H}, \mathrm{p}, 2 \mathrm{NCH}_{2} \underline{\mathrm{CH}_{2}} \mathrm{CH}_{2}, J=6.9\right) ; 2.55$ (4 H, t, $\left.2 \mathrm{NCH}_{2}, J=6.9\right) ; 3.44\left(2 \mathrm{H}, \mathrm{s}, \mathrm{C} \equiv \mathrm{CCH}_{2} \mathrm{~N}\right) ; 3.69-3.82\left(8 \mathrm{H}, \mathrm{m}, 4 \mathrm{OCH}_{2}\right) ; 3.85-3.97(4 \mathrm{H}$, m, $\left.2 \operatorname{ArOCH}_{2} \underline{\mathrm{CH}}_{2}\right) ; 4.14\left(4 \mathrm{H}, \mathrm{s}, 2 \mathrm{ArOCH}_{2} \mathrm{CH}_{2}\right) ; 6.97(2 \mathrm{H}, 2-\mathrm{H}, 5-\mathrm{H})$. Anal. Calcd. for $\mathrm{C}_{30} \mathrm{H}_{42} \mathrm{~N}_{2} \mathrm{O}_{5}$ (510.66): C, 70.56; H, 8.29; N, 5.49. Found: 70.72; H, 8.09; N, 5.61\%.

3,4-bis-(3-Diethylaminoprop-1-ynyl)dibenzo-18-crown-6 (16+17)a. A mixture of the compounds (16+17)a, $0.08 \mathrm{~g}(61.5 \%)$, mp 145-149 ${ }^{\circ} \mathrm{C}$ (from benzene-hexane) was obtained from mixture of the compounds $\mathbf{1 0}+\mathbf{1 1}(0.1 \mathrm{~g}, 0.2 \mathrm{mmol})$, paraformaldehyde $(0.02 \mathrm{~g}, 0.5 \mathrm{mmol})$, 
diethylamine 14a $(0.05 \mathrm{~mL}, 0.5 \mathrm{mmol}), \mathrm{Cu}(\mathrm{OAc})_{2}(50 \mathrm{mg}), 30 \% \mathrm{H}_{2} \mathrm{SO}_{4}(0.1 \mathrm{~mL})$ in boiling dioxane $(10 \mathrm{~mL})$. IR $(\mathrm{KBr}): v\left[\mathrm{~cm}^{-1}\right] 2143(\mathrm{C} \equiv \mathrm{C})$. $1 \mathrm{H} \mathrm{NMR}$ data: $\delta\left(\mathrm{CDCl}_{3}\right) 1.15(12 \mathrm{H}, \mathrm{t}, 4$ $\left.\mathrm{CH}_{2} \underline{\mathrm{CH}}_{3}, J=6.8\right) ; 2.65\left(8 \mathrm{H}, \mathrm{q}, 4 \underline{\mathrm{CH}}_{2} \mathrm{CH}_{3}, J=6.8\right) ; 3.65\left(4 \mathrm{H}, \mathrm{s}, 2 \mathrm{C} \equiv \mathrm{CCH}_{2} \mathrm{~N}\right) ; 4.05-4.06(8 \mathrm{H}$, m, $\left.2 \mathrm{CH}_{2} \mathrm{OCH}_{2}\right)$; 4.17-4.19 (8 H, m, $\left.4 \mathrm{ArOCH}_{2}\right)$; 6.80 (2 H, d, 5-H, 2'(5')-H, J = 8.4), 6.95 (2 H, d, 2-H, 5'(2')-H, $J=2.6$ ), 7.08 (2 H, dd, 4-H, 4'(3')-H, $\left.{ }^{1} J=8.4,{ }^{2} J=2.6\right)$. Anal. Calcd. for $\mathrm{C}_{34} \mathrm{H}_{46} \mathrm{~N}_{2} \mathrm{O}_{6}$ (578.74): C, 70.56; H, 8.01; N, 4.84. Found: C, 70.21; H, 8.09; N, 4.53\%.

3,3'(4')-bis-(3-Morpholinoprop-1-ynyl)dibenzo-18-crown-6 (16+17)b. The compounds $(\mathbf{1 6 + 1 7}) \mathbf{b}, 0.06 \mathrm{~g}(42.9 \%), \mathrm{mp} 128-132{ }^{\circ} \mathrm{C}$ (from benzene) were prepared from the mixture of compound 10+11 (0.1 g, $0.2 \mathrm{mmol})$, paraformaldehyde $(0.02 \mathrm{~g}, 0.5 \mathrm{mmol})$, morpholine 14b $(0.05 \mathrm{~mL}, 0.5 \mathrm{mmol}), \mathrm{Cu}(\mathrm{OAc})_{2}(50 \mathrm{mg}), 30 \% \mathrm{H}_{2} \mathrm{SO}_{4}(0.1 \mathrm{~mL})$ in boiling dioxane $(10 \mathrm{~mL})$. IR $(\mathrm{KBr}): v\left[\mathrm{~cm}^{-1}\right] 2155(\mathrm{C} \equiv \mathrm{C}) .1 \mathrm{H} \mathrm{NMR}$ data: $\delta\left(\mathrm{CDCl}_{3}\right) 2.68-2.59\left(4 \mathrm{H}, \mathrm{m}, \mathrm{N}\left(\underline{\mathrm{CH}}_{2} \mathrm{CH}_{2}\right)_{2} \mathrm{O}\right) ; 3.05$ $\left(4 \mathrm{H}, \mathrm{s}, 2 \mathrm{C} \equiv \mathrm{CCH}_{2} \mathrm{~N}\right) ; 4.05-4.06\left(16 \mathrm{H}, \mathrm{m}, 2 \mathrm{CH}_{2} \mathrm{OCH}_{2}, 2 \mathrm{O}\left(\underline{\mathrm{CH}_{2}} \mathrm{CH}_{2}\right)_{2} \mathrm{~N}\right) ; 4.17-4.19(8 \mathrm{H}, \mathrm{m}, 4$ $\left.\mathrm{ArOCH}_{2}\right) ; 6.88$ (2 H, d, 5-H, 5'(2')-H, $\left.J=8.4\right), 7.10$ (2 H, d, 2-H, 2'(5')-H, $\left.J=2.6\right), 7.08$ (2 H, dd, 4-H, 4'(3')-H, $J=8.4,2.6)$. Anal. Calcd. for $\mathrm{C}_{34} \mathrm{H}_{42} \mathrm{~N}_{2} \mathrm{O}_{8}$ (606.71): C, 66.42; H, 6.98; N, 4.62. Found: C, 66.21; H, 6.09; N, 4.53\%.

3,3'(4')-bis-(3-Piperidinoprop-1-ynyl)dibenzo-18-crown-6 $(16+17) c$ A mixture of the compounds $(\mathbf{1 6}+\mathbf{1 7}) \mathrm{c} 0.07 \mathrm{~g}(50 \%), \mathrm{mp} 126-130{ }^{\circ} \mathrm{C}$ (from benzene-hexane) was prepared from a mixture of the compounds $\mathbf{1 0 + 1 1}(0.1 \mathrm{~g}, 0.2 \mathrm{mmol})$, paraformaldehyde $(0.02 \mathrm{~g}, 0.5 \mathrm{mmol})$, piperidine $14 \mathbf{c}(0.05 \mathrm{~mL}, 0.5 \mathrm{mmol}), \mathrm{Cu}(\mathrm{OAc})_{2}(50 \mathrm{mg}), 30 \% \mathrm{H}_{2} \mathrm{SO}_{4}(0.1 \mathrm{~mL})$ in boiling dioxane $(10 \mathrm{~mL})$. IR (KBr): $v\left[\mathrm{~cm}^{-1}\right] 2210(\mathrm{C} \equiv \mathrm{C}) .1 \mathrm{H} \mathrm{NMR}$ data: $\delta\left(\mathrm{CDCl}_{3}\right)$ 1.42-1.56 $(2 \mathrm{H}, \mathrm{m}$, $\left.\left(\mathrm{CH}_{2}\right)_{2} \underline{\mathrm{CH}}_{2}\left(\mathrm{CH}_{2}\right)_{2}\right) ; 1.68\left(4 \mathrm{H}, \mathrm{p}, 2 \mathrm{CH}_{2} \underline{\mathrm{CH}}_{2}\left(\mathrm{CH}_{2}\right)_{3}, J=6.9\right) ; 2.59\left(4 \mathrm{H}, \mathrm{t}, 2 \mathrm{NCH}_{2}, J=6.9\right) ; 3.49$ $\left(4 \mathrm{H}, \mathrm{s}, 2 \mathrm{C} \equiv \mathrm{CCH}_{2} \mathrm{~N}\right) ; 4.05-4.06\left(8 \mathrm{H}, \mathrm{m}, 2 \mathrm{CH}_{2} \mathrm{OCH}_{2}\right) ; 4.17-4.18\left(8 \mathrm{H}, \mathrm{m}, 4 \mathrm{ArOCH}_{2}\right) ; 6.79$ (2 H, d, 5-H, 5'(2')-H, $J=8.4), 6.96$ (2 H, d, 2-H, 2'(5')-H, $J=2.6), 7.05$ (2 H, dd, 4-H, 4'(3')-H, $\left.{ }^{1} J=8.4,{ }^{2} J=2.6\right)$. Anal. Calcd. for $\mathrm{C}_{36} \mathrm{H}_{46} \mathrm{~N}_{2} \mathrm{O}_{6}(602.76)$ : C, 71.73; H, 7.69; N, 4.65. Found: C, $71.42 ; \mathrm{H}, 7.87$; N, 4.43\%.

\section{Acknowledgments}

This work was supported by the RFBR grant (02-03-32265), RFBR grant (02-03-32229), CRDF REC-008, “Integration” program grant of SB RAS, ACCU SB RAS (00-03-40135).

\section{References}

1. Hiraoka, M. Crown Compounds. Their Characteristics and Applications; Elsevier Scientific Publishing Company: New York, 1982.

2. Abel, E.; Maguire, G.E.M.; Meadows, E.S.; Murillo, O.; Jin, T.; Gokel, G.W. J. Am. Chem. Soc. 1997, 119, 9061. 
3. Brandsma, L.; Vasilevsky, S. F.; Verkruijsse, H. D. Application of Transition Metal Catalysts in Organic Synthesis; Springer-Verlag: Berlin, Heidelberg, New York, 1998, 335 p

4. Klyatskaya, S. V.; Tretyakov, E. V.; Vasilevsky S. F. Russian Chem. Bull., Int. Ed. 2001, $50,868$.

5. Sonogashira, K.; Tohda, Y.; Hagihara, N. Tetrahedron Lett. 1975, $50,4467$.

6. Tretyakov, E. V.; Knight, D. W.; Vasilevsky, S. F. J. Chem. Soc., Perkin Trans. 1 1999, 3721.

7. Hyde, E. M.; Shaw, B. L.; Shepherd, I. J. Chem. Soc., Dalton Trans. 1978, 1696.

8. Feigenbaum, W. M.; Novel, M. R. H. J. Polym. Sci. (A-1) 1971, 9, 817.

9. Kotlyar, S. A.; Gorodnyuk, V. P.; Gursky, P. N.; Konsdrat'eva, V. A.; Kryshina, E. V.; Ivanov, O.V. Methods of the preparation and practical application of nitro- and aminobenzo- crown ethers and their derivatives; NIITEH: Moscow, 1990, p 50.

10. Shchori, E.; Jagur-Grodzinski, J.; Shporer, M. J. Am. Chem. Soc. 1973, 95, 3842.

11. Dains, F. B.; Eberly, F. Org. Synth., Coll. 1943, $2,355$.

12. Dieck, H. A.; Heck, F. P. Organomet. Chem. 1975, 93, 259.

13. (a) Vasilevsky, S. F. (b) Tretyakov, E. V.; Usov, O. M.; Molin, Y. N.; Fokin, S. V.; Shwedenkov, Y. G.; Ikorskii, V. N.; Romanenko, G. V.; Sagdeev, R. Z.; Ovcharenko, V. I. Mendeleev Comm. 1998, 216. Tretyakov, E. V.; Samoilova, R. I.; Ivanov, Y. V.; Plyusnin, V. F;. Pashchenko, S. V.; Vasilevsky, S. F. Mendeleev Comm. 1999, 92.

14. Austin, W. B.; Bilow, N.; Kelleghan, W. J.; Lau K. S. Y. J. Org. Chem. 1981, 46, 2280.

15. Mannich, C.; Chang, F.T. Chem. Ber. 1933, 66, 418.

16. Tashmukhamedova, A. K.; Abdulaeva R. A.; Stempnevskaya, I. A.; Saifulina, N. J.; Adibekov, M. T. Bioorgan. Khim. 1978, 4, 806.

17. Grebenuyk, A. D.; Andreev, S. A.; Stempnevskaya, I. A.; Levkovich, M. G.; Tashmukhamedova, A. K. Khim. Geterocycl. Soed. 2000, 12, 1688.

18. Gorodnyuk V. P.; Grigorash, Z. Ya.; Chuprin, G. N.; Kotlyar, S. A. Zh. Obshch. Khim. 1998, 68, 1051.

19. Organic Syntheses, Coll. Vol. 2. Edited by Blatt, A., Ed.; New York, 1949, p 105.

20. Klyatskaya, S. V.; Tretyakov, E. V.; Vasilevsky S. F. Russian Chem. Bulletin. Int. Ed. 2002, 51,128 . 